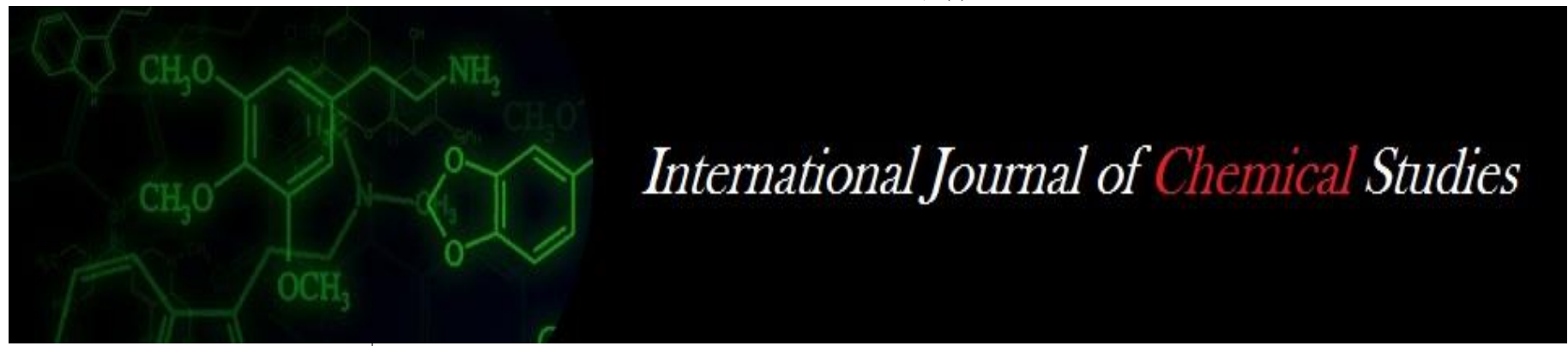

P-ISSN: 2349-8528

E-ISSN: 2321-4902

www.chemijournal.com

IJCS 2020; 8(5): 693-698

(C) 2020 IJCS

Received: 18-07-2020

Accepted: 16-08-2020

Andhale Anil Nanasaheb

Department of Soil and Water

Conservation Engineering,

College of Agricultural

Engineering and Technology,

Junagadh Agricultural

University, Junagadh, Gujarat, India

Parmar Hiteshkumar V

Department of Soil and Water

Conservation Engineering,

College of Agricultural

Engineering and Technology,

Junagadh agricultural

university, Junagadh, Gujarat, India

Pappu Kumar Paswan

Young Professional-II, Krishi

Vigyan Kendra, Purnea, Bihar,

India
Corresponding Author:

Andhale Anil Nanasaheb

Department of Soil and Water

Conservation Engineering,

College of Agricultural

Engineering and Technology,

Junagadh Agricultural

University, Junagadh, Gujarat, India

\section{Soil adjusted vegetation index (SAVI), in the Uben river basin of Gujarat}

\author{
Andhale Anil Nanasaheb, Parmar Hiteshkumar V and Pappu Kumar \\ Paswan
}

DOI: https://doi.org/10.22271/chemi.2020.v8.i5j.10381

\section{Abstract}

The Soil Adjusted Vegetation Index (SAVI) shows the vegetation status. The remote sensing based biophysical variable maps were used to estimate SAVI in Uben river catchment and command area of Gujarat state, India. Multi date satellite images of Landsat-8 for Rabi season, year 2018-19 were used in the ArcGIS 10.3 software to derive the Soil Adjusted Vegetation Index (SAVI). The maximum SAVI in the study area was 0.850 on February 19, 2019. The minimum SAVI in the study area was -0.491 on February 19, 2019.The average SAVI value ranged from 0.199 to 0.552 for wheat crop, 0.138 to 0.441 for coriander crop, 0.147 to 0.307 for cotton crop and 0.124 to 0.154 for waste land. In wheat and coriander crop SAVI increased up to 0.552 and 0.441 respectively from December 1, 2018 to January 18, 2019 and February 03, 2019 respectively and then after SAVI decreased. In cotton crop higher value of SAVI i.e. 0.307 was observed in December then after it was decreased due to harvesting of cotton crop. The SAVI value of waste land area shows nearly uniform trend.

Keywords: Soil adjusted vegetation index, Uben river, cotton crop

\section{Introduction}

The Multi Spectral Remote Sensing images are very efficient for obtaining a better understanding of the earth environment (Ahmadi and Nusrath, 2012) ${ }^{[1]}$. It is the Science and Art of acquiring information and extracting the features in form of Spectral, Spatial and Temporal about some objects, area or phenomenon, such as agriculture land, urban area, and vegetation and water resources without coming into physical contact of these objects (Karaburun and Bhandari (2010) ${ }^{[4]}$ The soil-adjusted vegetation index (SAVI) is accounts for and minimizes the effect of soil background conditions. The SAVI equation introduces a soilbrightness dependent correction factor, L that compensates for the difference in soil background conditions. SAVI is a means of monitoring density and vigour of green vegetation growth using the spectral reflectivity of solar radiation. The present study was undertaken in the Uben river catchment and command area located in Junagadh district of Gujrat, India. In the study the vegetation status was estimated using remote sensing.

\section{Study area and data collection}

The study area was the Uben river catchment and command area of Gujarat state (Fig. 1). The latitude and longitude of the study area are $21^{\circ} 25^{\prime} 31^{\prime \prime} \mathrm{N}$ to $21^{\circ} 44^{\prime} 36^{\prime \prime} \mathrm{N}$ (North latitude) and $70^{\circ} 12^{\prime} 32^{\prime \prime} \mathrm{E}$ to $70^{\circ} 47^{\prime} 25^{\prime \prime} \mathrm{E}$ (East longitude). 

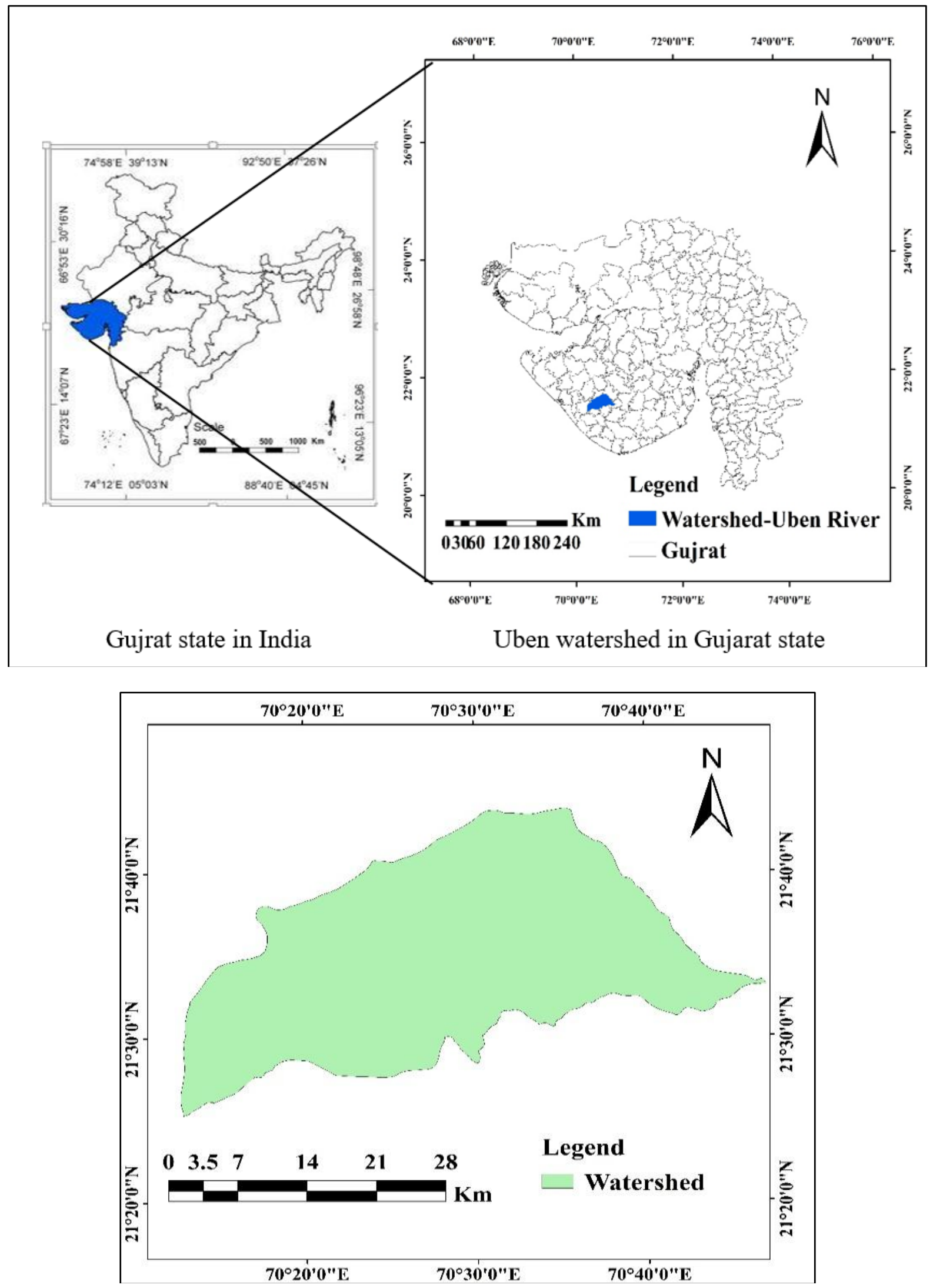

Uben catchment and dam command area

Fig 1: Location map of study area

\section{Data Collection}

The temporal satellite images of Landsat 8 were downloaded from USGS website (www.earthexplorer.usgs.gov) of Path 150 and Row 045for study area.The Operational Land Imager (OLI) and Thermal Infrared Sensor (TIRS) are instruments on board the Landsat 8 satellite, which was launched in February 2013.The satellite collects images of the Earth with a 16-day repeat cycle, referenced to the WRS-2. The approximate scene size is $170 \mathrm{~km}$ north-south by $183 \mathrm{~km}$ east-west. Landsat 8 provides spectral band files in GeoTIFF format. The Remote sensing and GIS software used for the study was ESRI's ArcGIS-ArcMap 10.3. The detail of different resolutions of Landsat-8 is given in Table 1 . 
Table 1: Band Designation in Landsat Data

\begin{tabular}{|c|c|c|c|c|c|c|c|}
\hline \multicolumn{8}{|c|}{ Landsat-8 } \\
\hline Sr. No. & Band & $\begin{array}{l}\text { Wave- length } \\
\text { (micr-ometer) }\end{array}$ & $\begin{array}{c}\text { Spatial Resolution } \\
\text { (meter) }\end{array}$ & Sr. No. & Band & \begin{tabular}{|c|} 
Wave-length \\
(micr-ometer)
\end{tabular} & $\begin{array}{l}\text { Spatial Reso- } \\
\text { lution (meter) }\end{array}$ \\
\hline 1. & Band 1-costal Aerosol & $0.43-0.45$ & 30 & 7. & Band 7 -SWIR 2 & $2.11-2.29$ & 30 \\
\hline 2. & Band 2-Blue & $0.45-0.51$ & 30 & 8. & Band $8-$ Panchromatic & $0.50-0.68$ & 15 \\
\hline 3. & Band 3-Green & $0.53-0.59$ & 30 & 9. & Band 9-Cirrus & $1.363-1.384$ & 30 \\
\hline 4. & Band 4-Red & $0.64-0.67$ & 30 & 10. & Band 10 - Thermal Infrared (TIRS) 1 & $10.60-11.19$ & $100 \times(30)$ \\
\hline 5. & Band 5-Near Infrared (NIR) & $0.85-0.88$ & 30 & 11. & Band 11 - Thermal Infrared (TIRS) 2 & $11.50-12.51$ & $100 \times(30)$ \\
\hline 6. & Band 6-SWIR 1 & $1.57-1.65$ & 30 & & & & \\
\hline
\end{tabular}

(www.earthexplorer.usgs.gov)

\section{Methodology}

Huete (1988) ${ }^{[3]}$ suggested the soil-adjusted vegetation index (SAVI) a vegetation index that accounts for and minimizes the effect of soil background conditions. The SAVI equation introduces a soil-brightness dependent correction factor, L that compensates for the difference in soil background conditions. Huete showed evidence that the vegetation lines (lines of equal vegetation) do not converge at a single point, and he selected the L-factor in SAVI based where lines of a specified vegetation density intersect the soil line. SAVI is a means of monitoring density and vigour of green vegetation growth using the spectral reflectivity of solar radiation. It was computed using the following equation.

$\mathrm{SAVI}=\frac{(\mathrm{NIR}-\mathrm{R})(1+\mathrm{L})}{(\mathrm{NIR}+\mathrm{R}+\mathrm{L})}$

Where $\mathrm{L}$ is the correction factor whose values range from 0 (high vegetation cover) to 1 (low vegetation). L value was taken as 0.5 in this study. The index had been designed to correct high soil reflectance in arid regions. Its value ranges between 0 (a very high vegetation cover) to 1 (a very low vegetation cover). Ghebrezgabher et al. (2016) [2] also givesSAVI's range from -1 to +1 , while +1 indicating healthy vegetation cover and lower values representing stressed vegetation.

\section{Results and Discussion}

Spatial Variability of Soil Adjusted Vegetation Index (SAVI) for Different Land Use

The Soil Adjusted Vegetation Index (SAVI) (Huete, 1988) ${ }^{[3]}$ accounts for and minimizes the effect of soil background conditions. The variable soil brightness constant (L) function improves vegetation sensitivity, particularly in high vegetation densities. The raster calculator in ArcGIS 10.3 was used to prepare the SAVI maps for different dates as shown in Fig. 2.The SAVI maps were prepared from the acquired Landsat images of dates i.e.December 01, 2018; December 17, 2018; January 02, 2019; January 18, 2019; February 03, 2019; February 19, 2019; March 07, 2019; March 23, 2019.

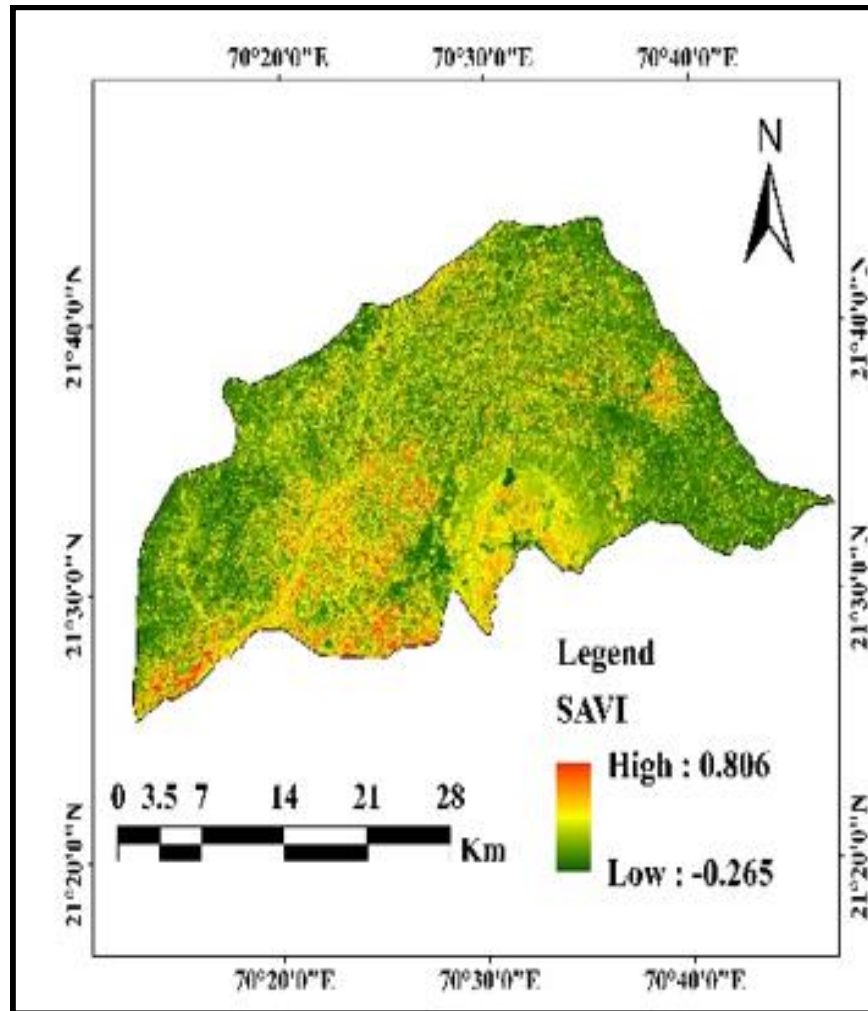

(a) $01 / 12 / 2018$

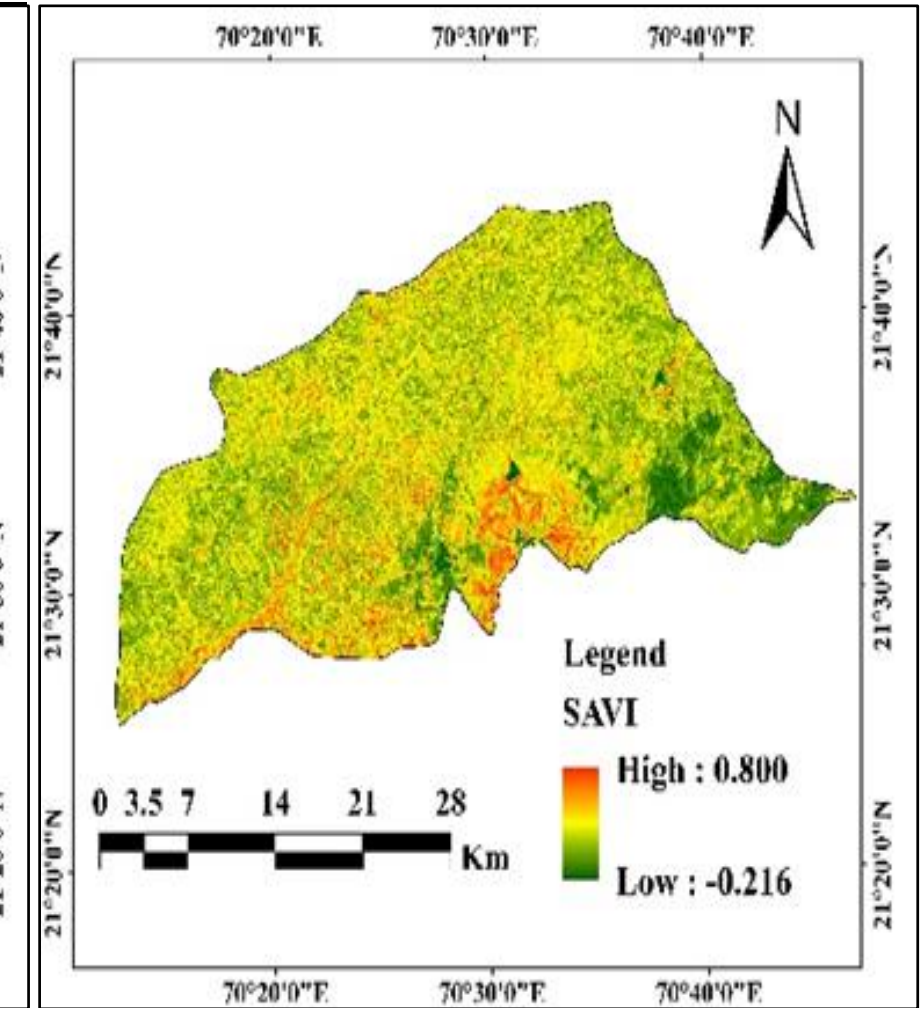

(b) $17 / 12 / 2018$ 


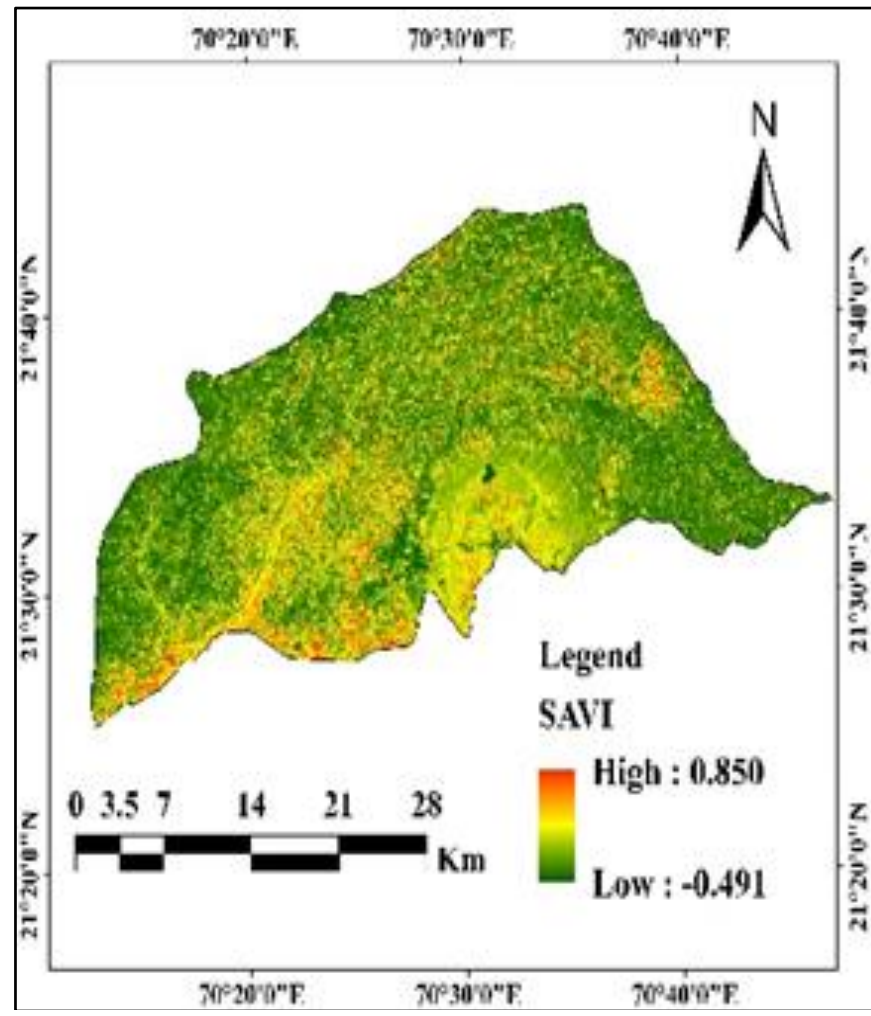

(c) $02 / 01 / 2019$

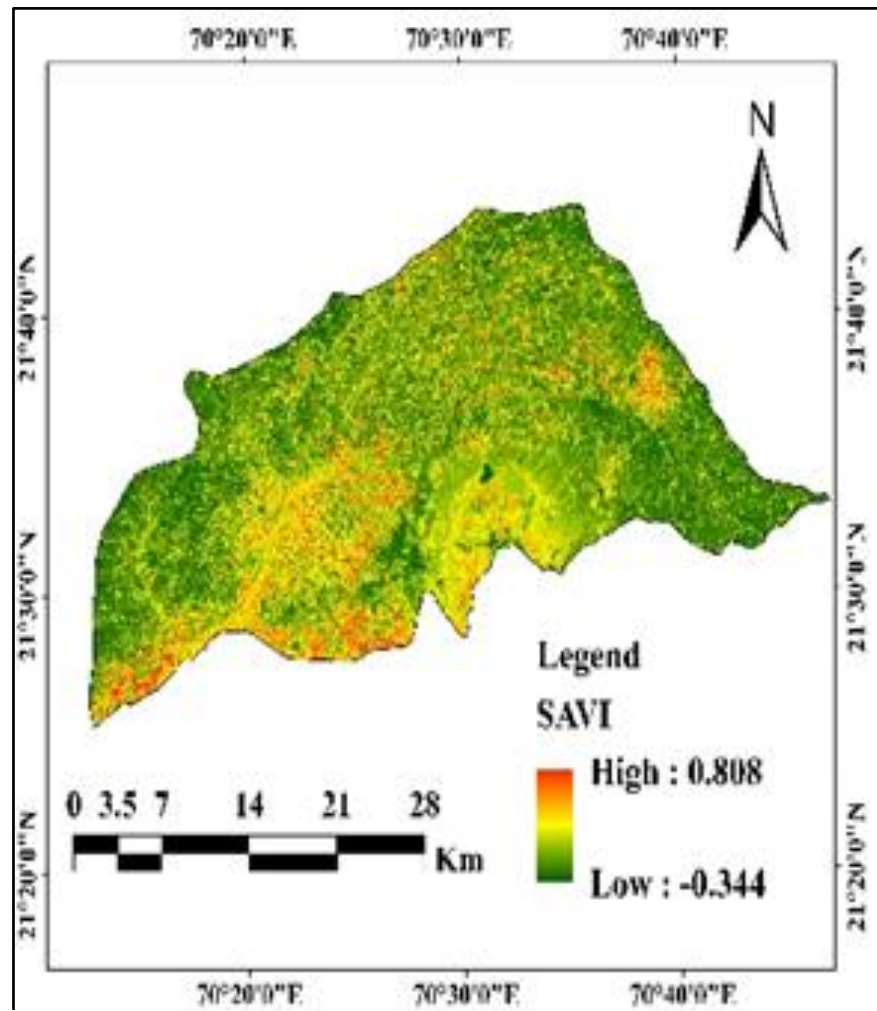

(e) $03 / 02 / 2019$

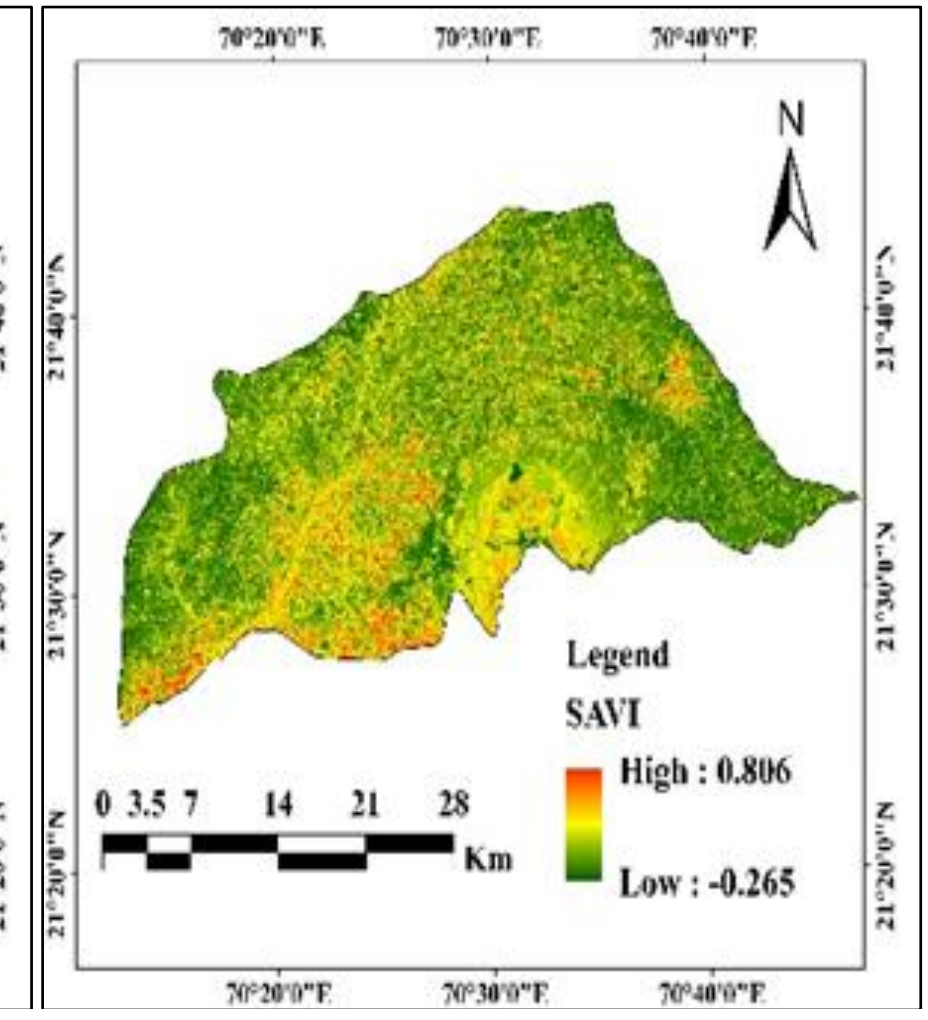

(d) $18 / 01 / 2019$

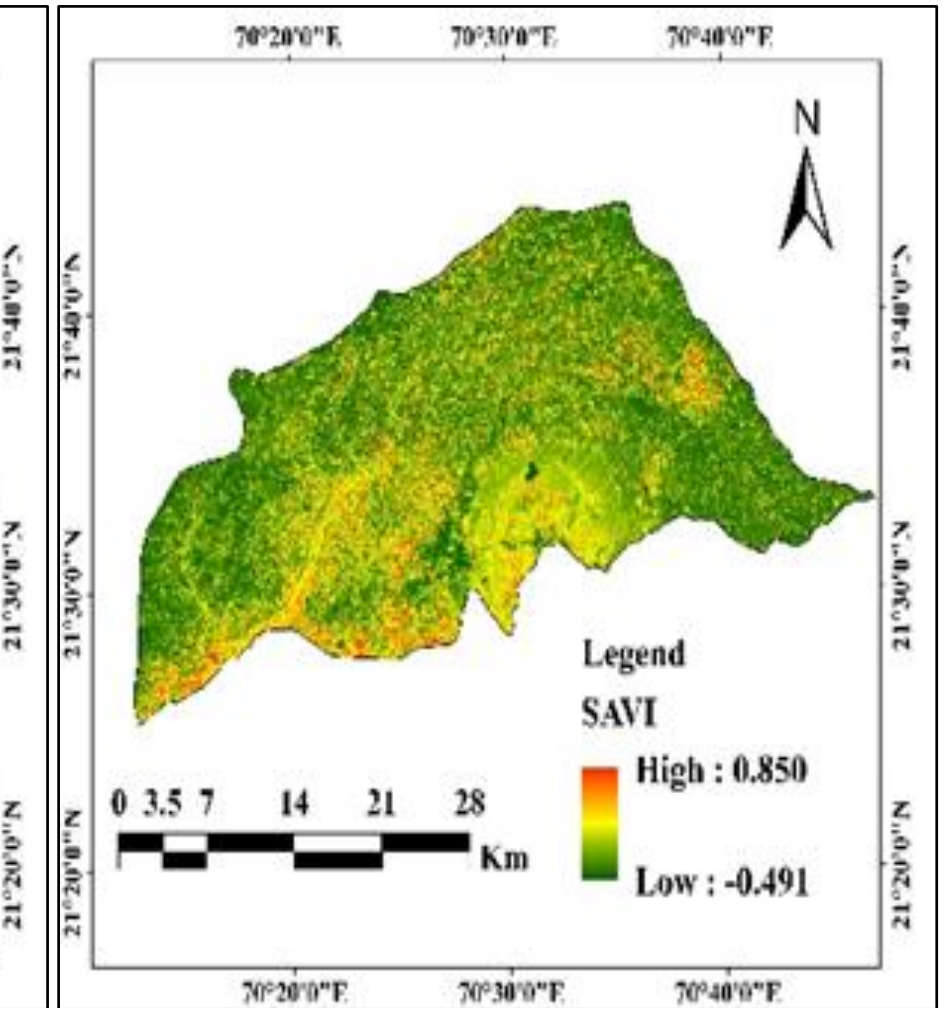

(f) $19 / 02 / 2019$ 


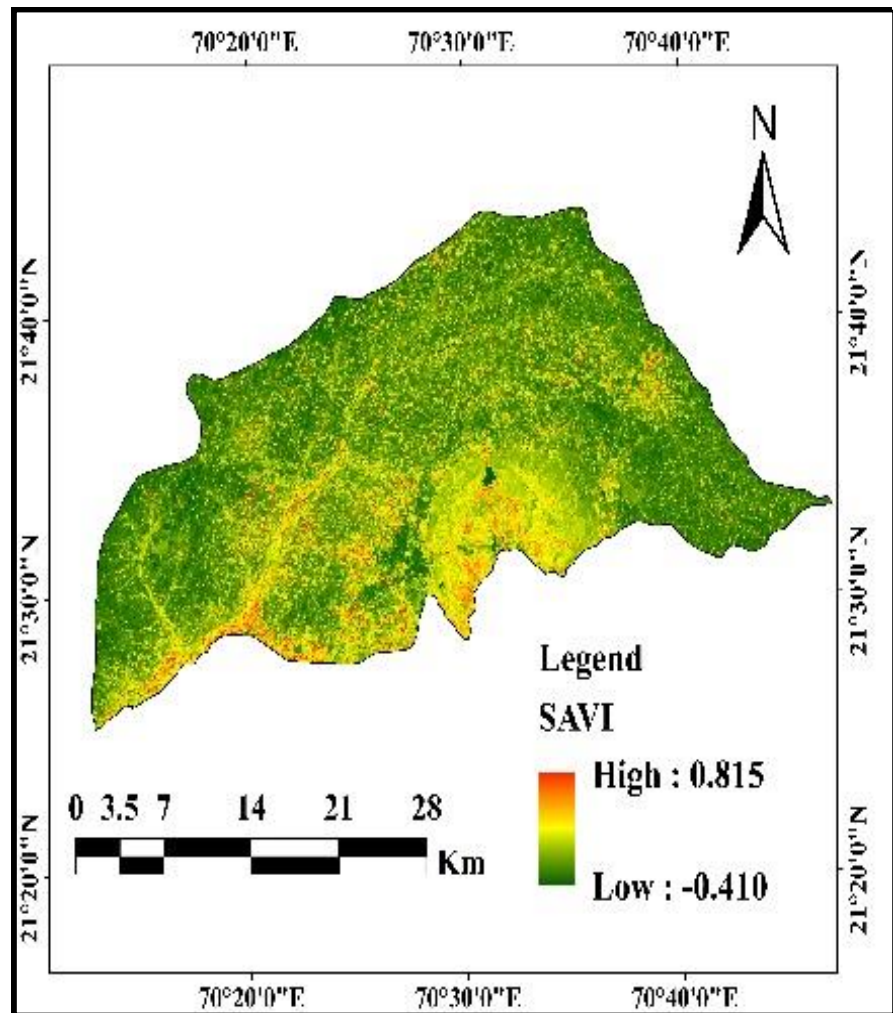

(g) $07 / 03 / 2019$

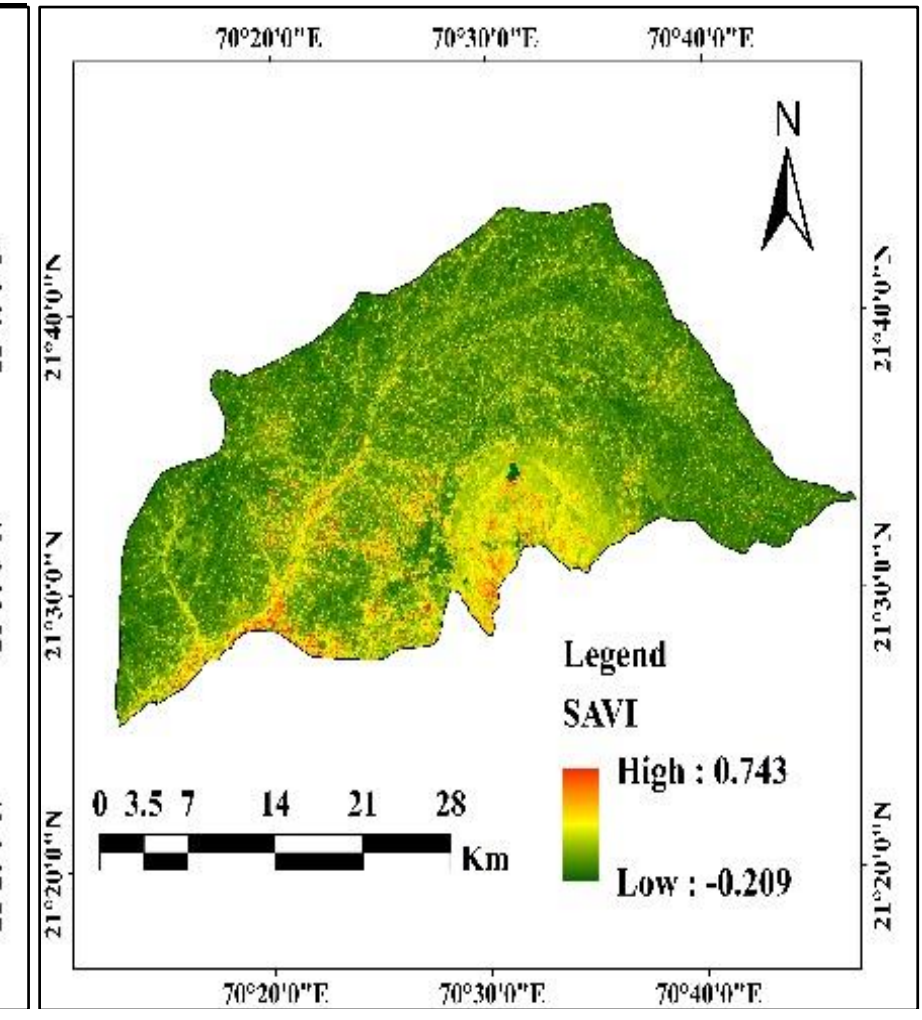

(h) $23 / 03 / 2019$

Fig 2: SAVI maps of study area using Landsat images

The values of SAVI for Rabi season, year 2018-2019 were ranged from -0.131 to $0.737,-0.216$ to $0.800,-0.211$ to 0.771 , -0.265 to $0.806,-0.344$ to $0.808,-0.491$ to $0.850,-0.410$ to 0.815 and -0.209 to 0.743 for the December 01, 2018; December 17, 2018; January 02, 2019; January 18, 2019; February 03, 2019; February 19, 2019; March 07, 2019 and March 23, 2019 respectively. The maximum SAVI in the study area was 0.850 on February 19, 2019.The minimum SAVI in the study area was -0.491 on February 19, 2019.

The SAVI value was increased from December 1, 2018 to January 18, 2019 in wheat crop i.e. 0.552 due to crop growth stage and then after it was decreased. This decrease in the SAVI value was due to the harvesting of crop and reduction in the area under crop. Similar trend of SAVI was found Raghavendra and Mohammed (2016) [5] for cropped land.SAVI map was also shows that in month of December maximum area was under crop and then after area under crop decreased due to harvesting of cotton crop. The minimum area under higher value of SAVI was observed during month of March, 2019. The area of Girnar forest also shows higher SAVI value (red colour in map).

\section{Temporal Variability of Soil Adjusted Vegetation Index (SAVI) for Different Land Use}

There are total nineteen locations were selected from study area; from which nine location indicate wheat crop, three location indicate coriander crop, three location indicate cotton crop and other four location indicate waste land. The SAVI for different land uses and temporal variability of SAVI for the period of December 1, 2018 to March 23, 2019 is given in Table 2. The trend of SAVI for different land use is shown in Fig. 3.

Table 2: Soil Adjusted Vegetation Index (SAVI) values for different land use

\begin{tabular}{|c|c|c|c|c|c|}
\hline \multirow{2}{*}{ Date } & \multicolumn{4}{|c|}{ SAVI } & \multirow{2}{*}{ Average SAVI value } \\
\cline { 2 - 5 } & Wheat crop & Coriander crop & Cotton crop & Waste land & \\
\hline $01 / 12 / 2018$ & 0.199 & 0.201 & 0.280 & 0.154 & 0.202 \\
\hline $17 / 12 / 2018$ & 0.403 & 0.274 & 0.307 & 0.140 & 0.312 \\
\hline $02 / 01 / 2019$ & 0.500 & 0.328 & 0.226 & 0.124 & 0.351 \\
\hline $18 / 01 / 2019$ & 0.552 & 0.430 & 0.196 & 0.128 & 0.387 \\
\hline $03 / 02 / 2019$ & 0.464 & 0.441 & 0.157 & 0.137 & 0.343 \\
\hline $19 / 02 / 2019$ & 0.386 & 0.381 & 0.173 & 0.153 & 0.303 \\
\hline $07 / 03 / 2019$ & 0.249 & 0.155 & 0.157 & 0.138 & 0.197 \\
\hline $23 / 03 / 2019$ & 0.221 & 0.138 & 0.147 & 0.141 & 0.179 \\
\hline
\end{tabular}



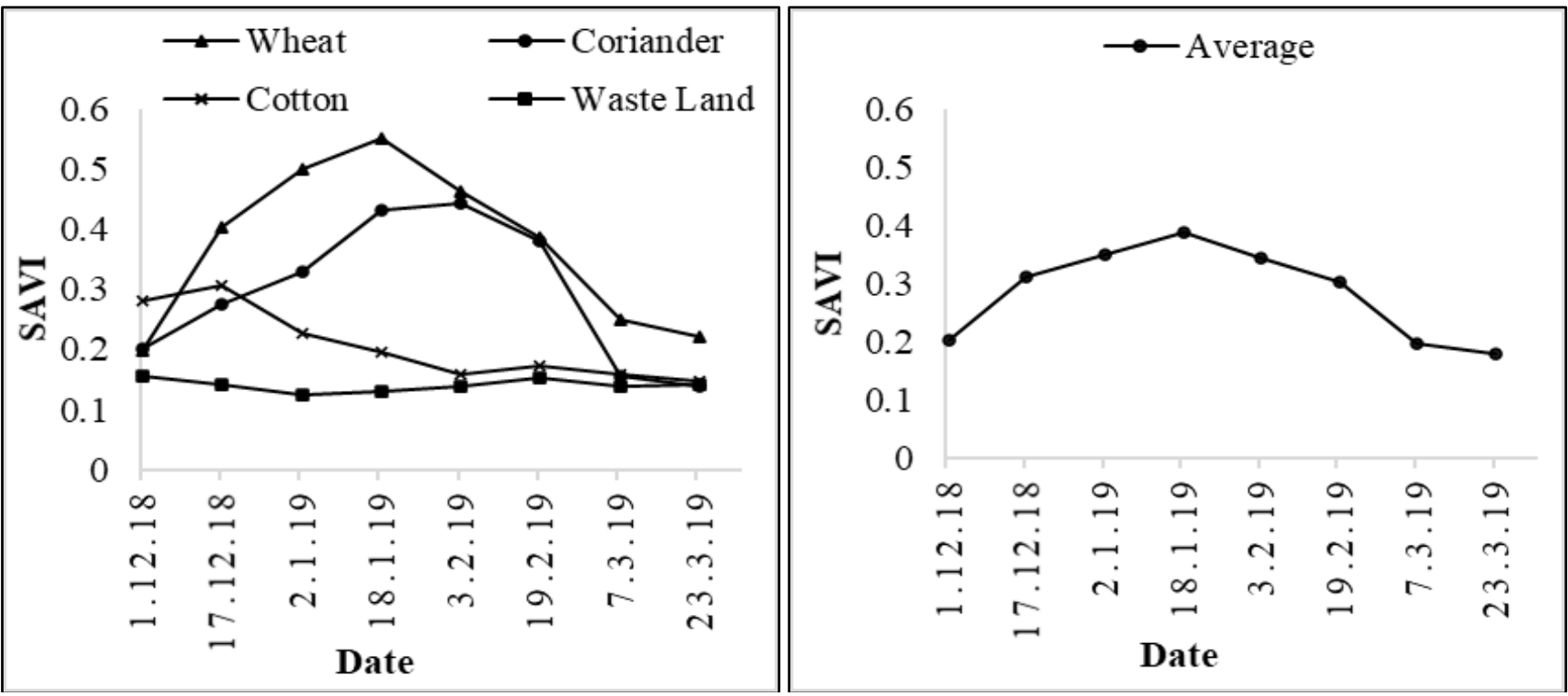

Fig 3: Temporal Variability of average SAVI for different Land Use

\section{Conclusions}

The average SAVI value ranged from 0.199 to 0.552 for wheat crop, 0.138 to 0.441 for coriander crop, 0.147 to 0.307 for cotton crop and 0.124 to 0.154 for waste land. In wheat and coriander crop SAVI increased up to 0.552 and 0.441 respectively from December 1, 2018 to January 18, 2019 and February 03, 2019 respectively and then after SAVI decreased. The SAVI values in the fields of wheat and coriander crop were higher which indicates good crop growth; while cotton and waste land showed lower SAVI values which indicate land with less vegetative cover. In cotton crop higher value of SAVI i.e. 0.307 was observed in December then after it was decreased due to harvesting of cotton crop. The SAVI value of waste land area shows nearly uniform trend.

Application of Research: The SAVI shows status of crop vegetation. Therefore, from SAVI crop growth stage can be finding. Remote sensing based SAVI is very usefull for drought monitoring in large scale area.

Research Category: Remote sensing

\section{Reference}

1. Ahmadi H, Nusrath A. Vegetation change Detection of Neka river in Iran by using remote sensing and GIS. J geography and Geology, 2012; 2(1):58-67.

2. Ghebrezgabher MG, Yang T, Yang X, Wang X, Khan M. Extracting and analyzing forest and woodland cover change in Eritrea based on landsat data using supervised classification. The Egyptian J Remote Sens. and Space Sci., 2016; 19:37-47.

3. Huete AR. A soil-adjusted vegetative index (SAVI). Remote Sens. Environ. 1988; 25:295-309.

4. Karaburun AA, Bhandari K. Estimation of $\mathrm{C}$ factor for soil erosion modelling using NDVI in Buyukcekmece watershed, Ozean. J applied sciences, 2010; 3:77-85.

5. Raghavendra BR, Mohammed AMA. Monitoring vegetation condition using spectral vegetation indices: a case study of rice crops in Raichur district, Karnataka, India. IOSR J Appl. Geo. and Geophysics. 2016; 4(2):6468. 